\title{
Multi-stressor Extremes Found on a Tropical Coral Reef Impair Performance
}

\author{
Noelle Lucey*, Eileen Haskett and Rachel Collin \\ Smithsonian Tropical Research Institute, Panama City, Panama
}

\section{OPEN ACCESS}

Edited by:

Nina Bednarsek,

Southern California Coastal Water

Research Project, United States

Reviewed by:

Yanyan Kang,

Hohai University, China

Ariel Katharine Pezner,

University of California, San Diego,

United States

Derek Manzello,

National Oceanic and Atmospheric Administration (NOAA), United States Kirk N. Sato, University of Washington,

United States

*Correspondence:

Noelle Lucey

noelle.lucey@gmail.com

Specialty section:

This article was submitted to

Coastal Ocean Processes,

a section of the journal

Frontiers in Marine Science

Received: 29 July 2020

Accepted: 17 November 2020

Published: 09 December 2020

Citation:

Lucey N, Haskett E and Collin R (2020) Multi-stressor Extremes Found on a Tropical Coral Reef Impair

Performance.

Front. Mar. Sci. 7:588764. doi: 10.3389/fmars.2020.588764
Global change has resulted in oceans that are warmer, more acidic, and lower in oxygen. Individually any one of these stressors can have numerous negative impacts on marine organisms, and in combination they are likely to be particularly detrimental. Understanding the interactions between these factors is important as they often covary, with warming promoting hypoxia, and hypoxia co-occurring with acidification. Few studies have examined how all three factors interact to affect organismal performance, and information is particularly sparse for tropical organisms. Here we documented a strong relationship between high temperatures, low dissolved oxygen (DO), and low $\mathrm{pH}$ in and around a tropical bay. We used these field values to inform two multistressor experiments. Each experimental factor had two levels, one representing current average conditions and the other representing current extreme conditions experienced in the area. We used sea urchin righting response as a measure of organismal performance for an important reef herbivore. In the first experiment 2-h exposures to a fully factorial combination of temperature, $\mathrm{DO}$, and $\mathrm{pH}$ showed that righting success was significantly depressed under low oxygen. To more fully understand the impacts of $\mathrm{pH}$, we acclimated sea urchins to control and low pH for 7 days and subsequently exposed them to the same experimental conditions. Sea urchins acclimated to control $\mathrm{pH}$ had significantly reduced righting success compared to animals acclimated to low $\mathrm{pH}$, and righting success was significantly depressed under hypoxia and high temperature, compared to normoxia and ambient temperature. These results show that short, $2 \mathrm{~h}$ exposures to the temperature and DO extremes that are already experienced periodically by these animals have measurable detrimental effects on their performance. The positive impact of reduced $\mathrm{pH}$ is evident only over longer, 7 days durations, which are not currently experienced in this area.

Keywords: hypoxia, global warming, ocean acidification, Echinometra, multiple stressor analysis, coral reef, ocean deoxygenation

\section{INTRODUCTION}

It is a truth almost universally acknowledged that the world's oceans are warming, becoming more acidic, and losing oxygen (Keeling et al., 2010; Gruber, 2011; Breitburg et al., 2018). Oceans have been rapidly warming since the 1950s (Cheng et al., 2019; IPCC, 2019). This has resulted in reduced global oceanic oxygen concentrations through increased water stratification and decreased oxygen solubility (Keeling et al., 2010; Schmidtko et al., 2017). Oceans also absorb about a quarter 
of the carbon dioxide $\left(\mathrm{CO}_{2}\right)$ in the atmosphere every year, which is making them more acidic (Doney et al., 2009; Le Quéré et al., 2009). Individually, changes in any one of these factors are likely to impact organismal performance and in severe cases may result in mortality (Diaz, 2001; Kroeker et al., 2010; Yao and Somero, 2014). However, because the three environmental stressors are mechanistically linked (Bopp et al., 2013; Gobler and Baumann, 2016), animals are likely to experience all three stressors in combination in many coastal systems (Figure 1) (Breitburg et al., 2015; Reum et al., 2016; Humphreys, 2017).

Most marine organisms need more oxygen when temperatures increase (Fry, 1971; Pörtner, 2010). In coastal habitats, this can result in a reduction in oxygen concentration as a result of increased community metabolism (Gunderson et al., 2016). With increasing organismal oxygen uptake, there is also increasing respiration, which produces carbon dioxide and reacts with the water decreasing the $\mathrm{pH}$. Concentrations of $\mathrm{pH}$ and dissolved oxygen (DO) show clear spikes during the day driven by daytime photosynthesis and steep declines at night driven by community respiration (Gobler and Baumann, 2016). The amplitude of these regular daily cycles can increase in response to external inputs, such as storm runoff, weather-driven increases in solar-radiation, and/or decreased wind intensity but are most strongly affected by warming (Tyler et al., 2009).

In addition to diel cycling, warming also clearly exacerbates metabolically-driven extremes in $\mathrm{pH}$ and $\mathrm{DO}$ on longer episodic or seasonal time scales in coastal systems (Baumann et al., 2014; Baumann and Smith, 2017). Coastal runoff due to intensifying storms, growing populations, and increasing nutrients from untreated wastewaters also fuel coastal community metabolism, and are particularly concerning in the tropics where resources to mitigate these issues are limited (Lonholdt, 2005; Knutson et al., 2010). As climate changes, these fluctuations are likely to become more pronounced (Boyd et al., 2016). These lines of evidence suggest that marine life may already be experiencing multiple stressful conditions at the same time, yet little is known about how these dynamics co-vary in tropical habitats, or what their biological impacts are.

Shallow-water tropical habitats, especially coral reefs which host a significant portion of global marine biodiversity, and estuaries which are important nursery grounds for many commercial species, may be at particular risk from these stressors (Duarte et al., 2013). Recent reviews have argued that modern reefs cannot be fully understood without explicitly considering the impacts of oxygen dynamics (Nelson and Altieri, 2019), and yet hypoxia, more than any other stressor, remains significantly under-studied in tropical locations (Altieri et al., 2017; Hughes et al., 2020). In fact, hypoxia-associated mass mortality events and dead zones associated with warm temperatures have recently been reported for the first time at several tropical sites (Laboy-Nieves et al., 2001; Díaz-Asencio et al., 2015; Altieri et al., 2017; van Tussenbroek et al., 2017). Another review has argued that areas experiencing combined hypoxia and acidification may be significantly under-reported, that natural variability is poorly documented, and that the harmful synergistic interaction between these two stressors are worryingly understudied (Gobler and Baumann, 2016).
One common way to think about the impacts these three cooccurring stressors may have on marine organisms is with aerobic scope, a measure of an organism's ability to take up oxygen from the environment and use it for fundamental activities such as feeding, reproduction, growth, and predator avoidance (Pörtner and Peck, 2010). A decline in aerobic scope can be visualized as a decreased capacity for oxygen uptake and decreased energy for these activities (Fry, 1971; Pörtner, 2010; Claireaux and Chabot, 2016). As temperature increases, aerobic scope is predicted to decrease due to the hindered capacity of the individual to deliver sufficient oxygen to its body tissues and can be visualized as a depressed performance curve (Figure 1) (Farrell et al., 2008). As environmental DO and/or $\mathrm{pH}$ decreases, aerobic scope is also predicted to decrease, further depressing performance curves (Pörtner and Farrell, 2008). Organism performance at all levels is therefore predicted to be reduced under increasing environmental temperatures, lowered $\mathrm{DO}$ and $\mathrm{pH}$, yet ecological validation is still needed (Verberk et al., 2016).

Our aim was to document temperature, DO, and $\mathrm{pH}$ conditions throughout a tropical bay and use those conditions to inform multi-factor stressor experiments to understand how current extreme conditions impact the performance of an ecologically important herbivore. Previous work with marine invertebrates has shown that short-term or intermittent exposures to modern-day extreme conditions can result in reduced organismal performance. For example, weekly exposures to $1 \mathrm{mg} / \mathrm{L}$ DO for less than $8 \mathrm{~h}$ resulted in morphological and metabolic changes in the fireworm, Hermodice carunculata (Lucey et al., 2020). The juvenile oyster, Crassostrea virginica, raised under diel oxygen cycles where concentrations dipped to $0.5 \mathrm{mg} / \mathrm{L}$ exhibited reduced growth rates (Keppel et al., 2016). Herbivory rates of a temperate sea urchin, an amphipod and a snail, all decreased after 48-h reductions of DO from 7.2 to $2.0 \mathrm{mg} / \mathrm{L}$ but not after reductions of $\mathrm{pH}$ from 7.9 to 7.4 , and the combination of the two stressors had the same effect as the hypoxia alone ( $\mathrm{Ng}$ and Micheli, 2020). Abalone exposed to a 24-h combination of reduced $\mathrm{pH}(7.5)$ and $\mathrm{DO}(5 \mathrm{mg} / \mathrm{L})$ once every 15 days, showed decreased growth and survival compared to controls, as did those exposed only to reduced DO (Kim et al., 2013). Despite these examples, there are few studies that (1) seek to determine if modern-day extremes can have significant impacts on marine organisms and (2) test the effects of multiple stressors in combination (see: Gobler and Baumann, 2016; Gunderson et al., 2016). High temperatures may exacerbate the effects of deoxygenation and acidification making these issues particularly important in the tropics. The objectives of this study were therefore to determine the extreme temperature, $\mathrm{pH}$, and DO values in a tropical reef environment during the last 3 years, and experimentally test the performance of a reef herbivore, the sea urchin Echinometra lucunter, using two fully factorial multi-stressor experiments based on measured $\mathrm{pH}$, DO, and temperature values and exposure times. In the first experiment, sea urchins were exposed to stressors for $2 \mathrm{~h}$ and then their ability to right themselves was measured. Righting reflects the ability of the feet and spines to function, which is vital to (1) remain attached to the substrate, (2) to find crevices for protection, (3) move around and forage (Barry et al., 2014), and (4) recover 


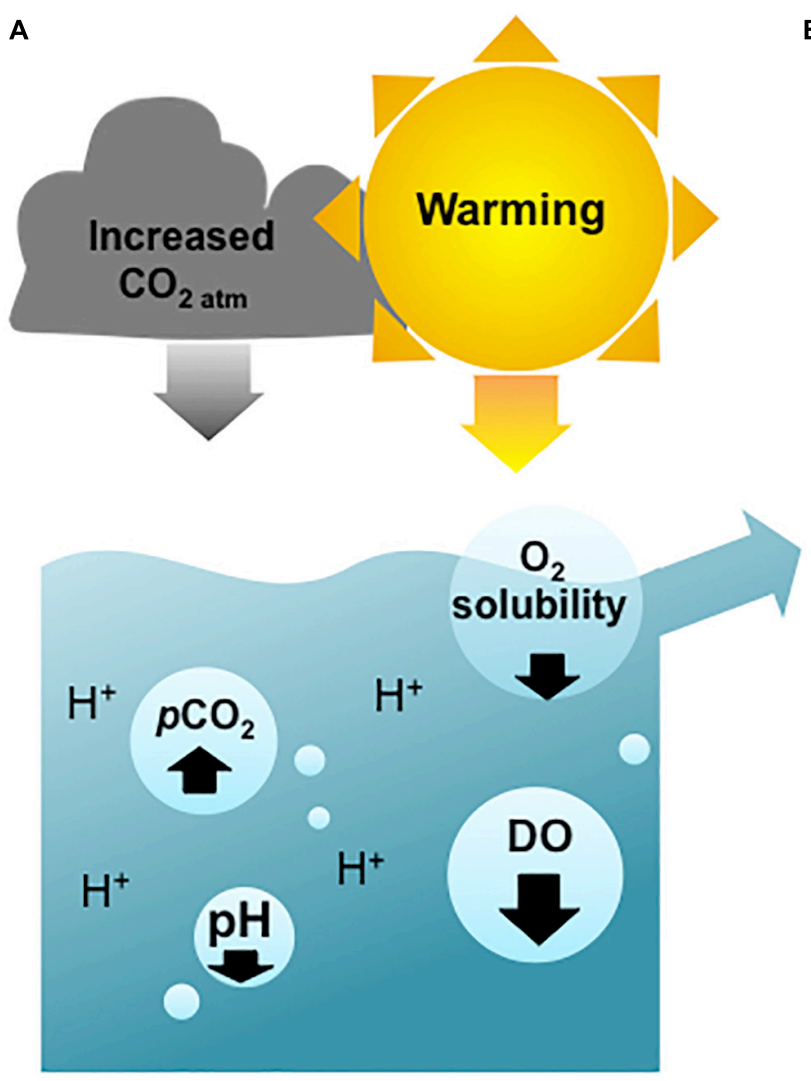

\section{B}

\section{Shrinking thermal niches}

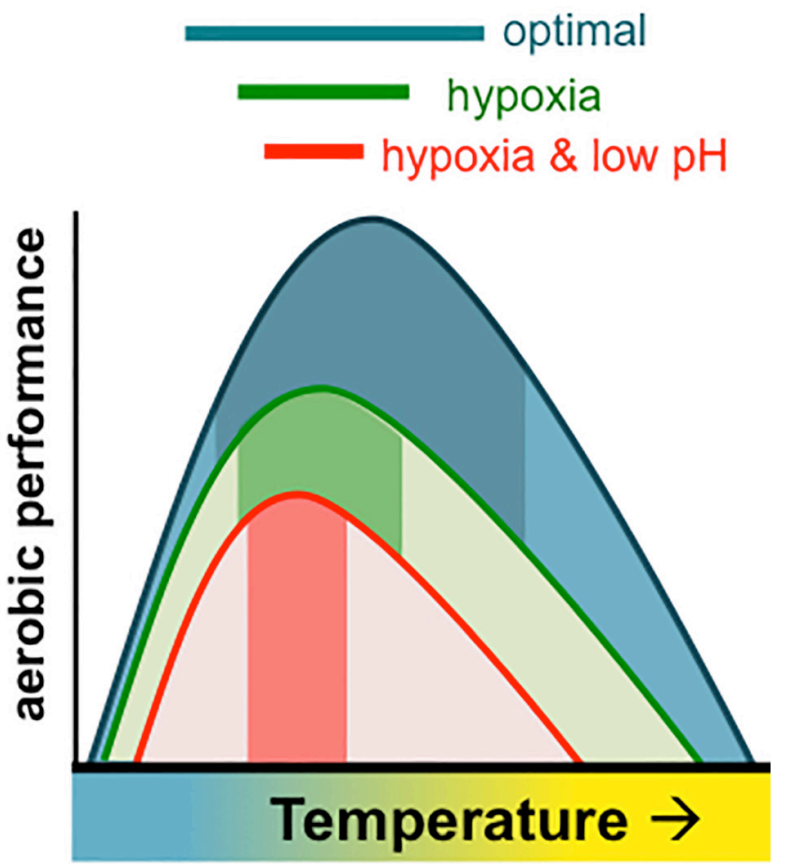

FIGURE 1 | (A) Graphical depiction of atmospheric warming represented as the sun, and increasing atmospheric carbon dioxide $\left(\mathrm{CO}_{2 a t m}\right)$ as the cloud, together driving ocean warming, decreasing dissolved oxygen (DO), and lowering $\mathrm{pH}$. The partial pressure of $\mathrm{CO}_{2}\left(\mathrm{pCO}_{2}\right)$ increases from both increasing atmospheric $\mathrm{CO}_{2}$ that is absorbed into the seawater (i.e., ocean acidification), as well as from biological activity (i.e., respiration) in the marine environment. (B) Scheme explaining how these differing stressors are expected to physiologically affect organismal performance, adapted from Pörtner and Farrell (2008). Dark shading within the curves represents the thermal window in which aerobic performance is possible under the different stressor combinations (blue $=$ optimal, green $=$ hypoxia, red $=$ hypoxia and low $\mathrm{pH} / \mathrm{OA}$ ). It is thought that decreasing oxygen availability due to hypoxia and/or low pH can each result in narrowing thermal windows.

if they are somehow dislodged. In the second experiment, we replicated this after first exposing sea urchins to seven days of low $\mathrm{pH}$. We did not expect sea urchin performance, measured as righting success, to be negatively affected by the short 2-h exposures to single-stressor conditions based on measurements in the field; however, we did expect the combination of all three stressors (low $\mathrm{pH}$, high temperature, and low DO) to have some negative effects. We also expected sea urchins that were exposed to low $\mathrm{pH}$ conditions for multiple days to be even more negatively affected by multiple stressors. The results of this study provide a current baseline for temperature, oxygen, and $\mathrm{pH}$ values on one well-studied tropical coastline, and insight into the relative importance of these specific stressor combinations on an abundant and important herbivore.

\section{MATERIALS AND METHODS}

\section{Study Site}

Almirante Bay is a large semi-enclosed bay on the Northwest Caribbean coast of Panama (Figure 2). Shallow-water ecotypes include mangroves, seagrass beds, fringing, and patch reefs as well as sponge gardens and soft bottoms that are no deeper than $25 \mathrm{~m}$. While this region does not experience large fluctuations in seawater temperature, environmental monitoring has recently detected seasonal changes in a hypoxic water mass in the deep water closest to the mainland. Between August and December, the hypoxic conditions expand and shoal (Lucey et al., 2020), and in recent years, this has caused significantly mortality of corals and associated marine life on reefs as shallow as $3 \mathrm{~m}$ (Johnson et al., 2018). However, shallow reefs that remain untouched by episodic hypoxia shoaling from depth can also experience hypoxia at night due to diel DO cycling (Lucey et al., 2020).

\section{Study Organism and Performance}

Sea urchins are ecologically important herbivores in shallowwater environments at all latitudes, and are often drivers of benthic community structure (Steneck, 2020). In the Caribbean, E. lucunter occurs on shallow exposed reefs and rocky shores (McPherson, 1965; Ebert et al., 2008; Sangil and Guzman, 2016) where their burrows may contribute significantly to erosion and increased habitat complexity (McLean, 1967; 


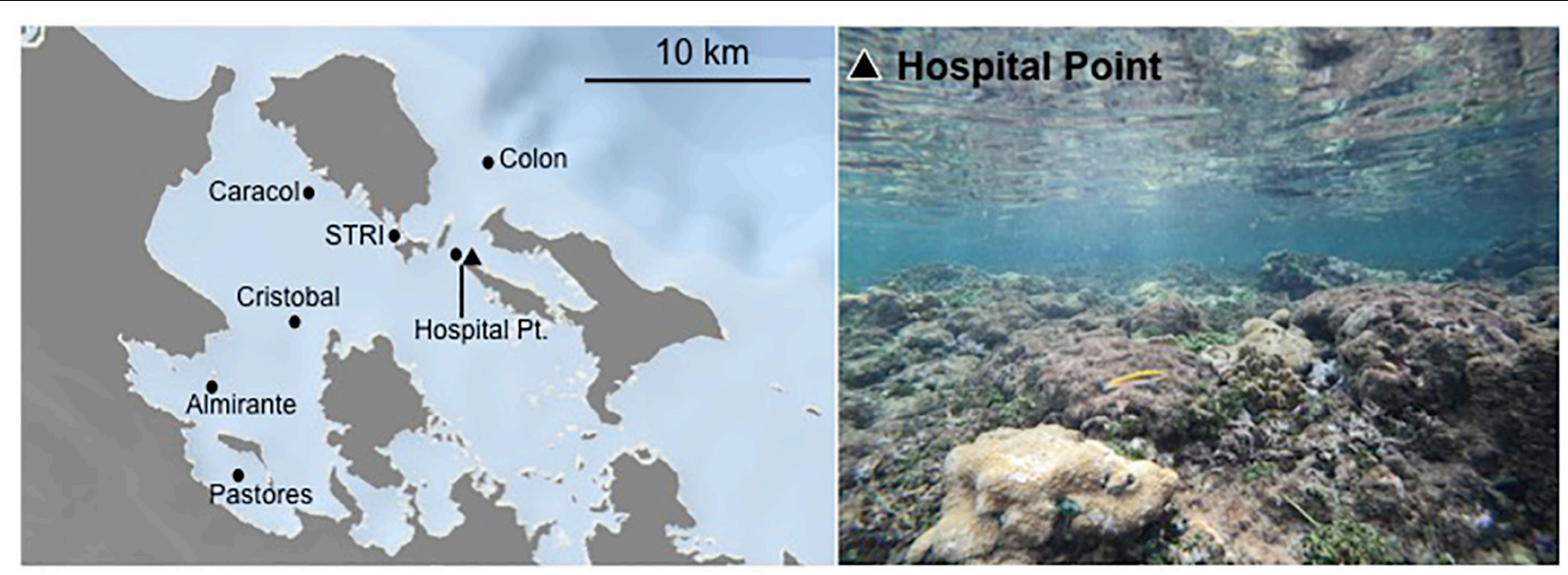

FIGURE 2 | Map of Almirante Bay showing the seven long-term monitoring sites (black dots), with sites "Pastores" and "Almirante" closest to the mainland and "Colon" outside the bay in the open ocean. Continuous monitoring on the Hospital Point reef, where animals were also collected from, is shown on the map as a black triangle and in the photograph on the right.

Schoppe and Werding, 1996). E. lucunter are most abundant at 1-5 $\mathrm{m}$ but have been found as deep as $45 \mathrm{~m}$ (McPherson, 1965). Previous research in Bocas del Toro has demonstrated that E. lucunter is one of the most thermally tolerant sea urchin species in the Caribbean (Collin et al., 2018; Perricone and Collin, 2019). To measure adult performance, we used the ability of upturned animals to turn over (righting response; Brothers and McClintock, 2015; Challener and McClintock, 2017; Collin et al., 2018). The righting response has been used to assess the impacts of temperature on echinoderms for 80 years (Kleitman, 1941; Farmanfarmaian and Giese, 1963; Lawrence and Cowell, 1996; Brothers and McClintock, 2015), and presumably requires coordinated sensory and locomotory functions, and therefore reflects whole organism function.

\section{Environmental Conditions}

To determine the most extreme values of $\mathrm{DO}, \mathrm{pH}$, and temperature throughout the bay over the last 3 years, we analyzed physical monitoring data measured at seven sites between June 2017 and March 2020. Monitoring sites represent the spatial heterogeneity of the area, extending from the mainland, through the bay and in the open ocean (Figure 2). Data were collected weekly in the mid-morning by recording depth profiles of parameters throughout the water column with a YSI multiparameter sonde (YSI EXO2 and EXO optical DO-accuracy $\pm 0.1 \mathrm{mg} / \mathrm{L}$; $\mathrm{pH}$ Smart Sensors-accuracy 0.02 units; and Temperature Sensors-accuracy $\pm 0.01^{\circ} \mathrm{C}$, Yellow Springs, United States) as part of the Smithsonian Tropical Research Institute's (STRI's) environmental monitoring program. The sensors were calibrated monthly following the manufacturers instructions (see Supplementary Material for details). We used values measured approximately $1 \mathrm{~m}$ above the seafloor of each site $(\sim 15-20 \mathrm{~m})$ to comprehensively represent daytime benthic conditions through the 3-year time period.
To determine how the 24 -h diel conditions vary on a shallow coral reef, we deployed $\mathrm{DO}, \mathrm{pH}$, conductivity, and temperature loggers near one of the long-term monitoring sites, Hospital Point. This is a well-exposed coral reef location, with significant water flow from offshore. Loggers were deployed between July and October 2019 at Hospital Point at $3 \mathrm{~m}$ depth and recorded measurements once every hour (HoboOnset loggers: U26-001 HOBO DO Logger-accuracy: $0.2 \mathrm{mg} \mathrm{L}^{-1}$; U24-002 Conductivity Logger accuracy-5\%; MX2501 pH and temperature logger-accuracy $\pm 0.10 \mathrm{pH}$ units and $0.1^{\circ} \mathrm{C}$, Onset, MA). Data were downloaded and sensors were cleaned and calibrated monthly according to the manufacture's protocols. Conductivity and temperature measurements were used to adjust DO measurements using HoboPro Software. Measurement precision was based on comparisons to measurements made in the field before and after calibration checks with a YSI Pro2013 multi-parameter handheld (accuracy: DO $0.2 \mathrm{mg} / \mathrm{L}$, Temp. $0.35^{\circ} \mathrm{C}, \mathrm{pH} 0.2$, Conductivity $0.5 \%$ ). Further details on calibration and quality control for both the 3-year weekly monitoring dataset and the 3-month hourly dataset are in the Supplementary Material.

\section{Experimental Procedures}

Echinometra lucunter adults were collected from the reef site near Hospital Point where the loggers were deployed (Figure 2). All sea urchins were gently detached from reef and rock substrate between 0 and $3 \mathrm{~m}$ depths and placed in coolers of fresh seawater on the boat out of direct sunlight. Within an hour of collection, all sea urchins were transported to the Bocas del Toro Research Station (BRS) and placed in clean holding tanks with unfiltered, continuously flowing seawater and air bubbling to ensure fully oxygenated, ambient temperature seawater conditions. Large rocks with algae were added for shelter and food. In the first experiment, sea urchins were kept in these holding tanks for a maximum of 7 days until the trials and 
experiments began, with an average holding time of 3.5 days. In the second experiment, they were kept for a maximum of 18 days, with an average holding time of 11.5 days. Temperature, DO, $\mathrm{pH}$, and salinity were measured with the YSI Pro2013 multiparameter handheld device at the collection site and daily in all holding tanks.

\section{Experiment 1}

Sea urchins were collected during the month of May 2019 and exposed to a fully factorial combination of two $\mathrm{pH}$ levels: low 7.6 and control 8.1, two temperatures: ambient $29^{\circ} \mathrm{C}$ and high $32^{\circ} \mathrm{C}$, and two DO levels: $1.5 \mathrm{mg} / \mathrm{L}$ hypoxic and $5.6 \mathrm{mg} / \mathrm{L}$ normoxic (Table 1). Experimental exposures were maintained at these levels for $2 \mathrm{~h}$ at which point sea urchins were flipped upside-down and righting ability and time measured. Treatment levels were based on the values measured in the field and approximately reflect the more extreme values that occurred infrequently in both timeseries datasets (Table 2). The "control" values reflect the ambient values, which approximately corresponded with the mid-point of the range of values recorded (Table 2).

Trial tanks with $4 \mathrm{~L}$ of fresh seawater each held three individuals. Trial tanks were brought to the correct experimental conditions with the animals inside in a 15-min ramping period before trials began. Depending on the treatment, this was accomplished by bubbling regular air for control conditions, and either pure $\mathrm{N}_{2}$ gas to lower $\mathrm{DO}, \mathrm{CO}_{2}$ gas mixed with air to lower $\mathrm{pH}$, and/or adding small quantities of warmed seawater to reach correct temperature levels. Trial tanks were placed in a water bath with submersible aquarium pumps and heaters to maintain trial temperatures. After the ramping period, water conditions were monitored every $15 \mathrm{~min}$ in each tank for the 2-h duration of the trial. To keep seawater parameters stable during trials, either $\mathrm{N}_{2}$ or regular air was bubbled directly into tanks as needed to maintain DO. Warm seawater and low-pH seawater, made from bubbling $\mathrm{CO}_{2}$ gas, was prepared before trials and added in small increments if adjustments were necessary throughout the experiment to maintain temperature and $\mathrm{pH}$. Trials were conducted sequentially (see below).

TABLE 1 | Mean and standard deviation of environmental parameters measured in the laboratory during the experimental treatments, and during the 7-day $\mathrm{pH}$ acclimation phase of the second experiment.

\begin{tabular}{lccc}
\hline Factor & Level & $\begin{array}{c}\text { Experiment 1 } \\
\text { mean } \pm \text { SD, } \boldsymbol{n}\end{array}$ & $\begin{array}{c}\text { Experiment 2 } \\
\text { mean } \pm \text { SD, } \boldsymbol{n}\end{array}$ \\
\hline Temperature ${ }^{\circ} \mathrm{C}$ & Ambient & $29.2 \pm 0.19,15$ & $29.1 \pm 0.29,38$ \\
& High & $31.9 \pm 0.27,15$ & $32.1 \pm 0.33,41$ \\
Dissolved oxygen $\mathrm{mg} / \mathrm{L}$ & Normoxic & $5.6 \pm 0.35,15$ & $5.6 \pm 0.15,36$ \\
& Hypoxic & $1.5 \pm 0.09,16$ & $1.4 \pm 0.14,36$ \\
$\mathrm{pH}$ & Control & $8.1 \pm 0.08,14$ & $7.6 \pm 0.05,42$ \\
& Low & $7.6 \pm 0.04,15$ & $8.1 \pm 0.09,27$ \\
Acclimation $\mathrm{pH}$ & Control & & $8.0 \pm 0.05,9^{*}$ \\
& Low & & $7.6 \pm 0.06,8^{*}$ \\
\hline
\end{tabular}

Measurements were taken for each trial tank ( $n$ ).

*Number of acclimation tanks sea urchins were maintained in during the acclimation phase.
TABLE 2 | Environmental parameters measured in the field from weekly daytime measurements made from June 2017 to March 2020 near the seafloor, and from hourly measurements made July to October 2019 at the collection site, Hospital Point (in italics).

\begin{tabular}{|c|c|c|c|}
\hline $\begin{array}{l}\text { Site, } \\
\text { depth (m) }\end{array}$ & $\begin{array}{l}\text { pH mean } \\
\text { (min, max) }\end{array}$ & $\begin{array}{c}\text { DO mg/L mean } \\
(\text { min, max })\end{array}$ & $\begin{array}{c}\text { Temp. }{ }^{\circ} \mathrm{C} \text { mean } \\
(\min , \mathrm{max})\end{array}$ \\
\hline $\begin{array}{l}\text { Almirante, } \\
22.6 \mathrm{~m}\end{array}$ & $7.91(7.59,8.47)$ & $1.74(0.11,5.56)$ & $29.00(26.83,30.76)$ \\
\hline $\begin{array}{l}\text { Pastores, } \\
24.1 \mathrm{~m}\end{array}$ & $7.92(7.58,8.45)$ & $1.89(0.06,5.51)$ & $28.96(26.87,30.56)$ \\
\hline $\begin{array}{l}\text { Cristobal, } \\
23.3 \mathrm{~m}\end{array}$ & $8.04(7.59,8.51)$ & $3.62(0.37,6.06)$ & $28.80(26.80,30.55)$ \\
\hline $\begin{array}{l}\text { Caracol, } \\
16.5 \mathrm{~m}\end{array}$ & $8.12(7.58,8.55)$ & $5.08(0.53,6.42)$ & $28.70(26.52,30.72)$ \\
\hline $\begin{array}{l}\text { STRI, } \\
22.1 \mathrm{~m}\end{array}$ & $8.06(7.65,8.49)$ & $4.05(0.84,6.04)$ & $28.78(26.81,30.65)$ \\
\hline $\begin{array}{l}\text { Hospital Pt., } \\
20.5 \text { m }\end{array}$ & $8.11(7.78,8.51)$ & $4.75(2.38,6.39)$ & $28.73(26.77,30.39)$ \\
\hline $\begin{array}{l}\text { Colon, } \\
20.2 \mathrm{~m}\end{array}$ & $8.16(7.93,8.53)$ & $5.72(4.95,6.29)$ & $28.31(26.77,30.23)$ \\
\hline $\begin{array}{l}\text { Hospital Pt., } \\
3.0 \mathrm{~m}\end{array}$ & $8.09(7.81,8.64)$ & $5.21(0.81,13.89)$ & $29.81(27.70,32.70)$ \\
\hline
\end{tabular}

Following the $2 \mathrm{~h}$ experimental exposure, sea urchins were flipped and time until they were fully righted was measured. Any sea urchin that did not right after $10 \mathrm{~min}$ was recorded as a failed righting response. Successful righting usually occurred in $<1 \mathrm{~min}$. After righting was measured, urchins were returned to separate holding tanks and $48 \mathrm{~h}$ post-trial survival was measured. All animals were released following the 48 -h survival analysis at a site $5 \mathrm{~km}$ away (i.e., STRI site) from the collection site to ensure individuals were not re-tried. Trials were run daily between May and June 2019. A total of 172 individuals were tested over eight treatment combinations, with three urchins per trial tank, for a total of six to eight trials per treatment.

\section{Experiment 2}

The second experiment measured the performance of $E$. lucunter under the three stressors as in Experiment 1, but first urchins were exposed to 7 days of control or chronically low $\mathrm{pH}$. Sea urchins were collected from the same site as above between November and December 2019. After being held in ambient, oxygenated holding tanks with algae-covered rocks/food for an average of 11.5 days, they were placed in $50 \mathrm{~L}$ acclimation tanks (18 individuals/acclimation tank). Four control acclimation tanks were maintained at $\mathrm{pH}>8.00$ with bubbling air, while four low $\mathrm{pH}$ acclimation tanks were maintained at $\mathrm{pH} 7.6 \pm 0.06$ SE by bubbling air-mixed $\mathrm{CO}_{2}$ directly into tanks. Temperature and oxygen were kept at ambient levels $\left(29^{\circ} \mathrm{C}\right.$ and $\left.>6.0 \mathrm{mg} / \mathrm{L}\right)$ with submersible aquarium heaters and air pumps maintained. Seawater was refreshed at a rate of $8 \mathrm{~L} / \mathrm{h}$ in all acclimation tanks. Temperature and DO values were recorded every $10 \mathrm{~min}$ (HOBO U30 Station with S-TMB-M0xx temperature probesaccuracy $\pm 0.2^{\circ} \mathrm{C}$; Barreleye Designs DO Controllers with Atlas Scientific galvanic DO probes-accuracy $\pm 0.05 \mathrm{mg} / \mathrm{L}$ ). After the 7 days $\mathrm{pH}$ exposure, trials were performed following the same protocol as in the first experiment. A total of 299 individuals were 
tested over 16 treatment combinations, with three urchins per trial tank for a total of five to six trials per treatment.

In both experiments, the order of trial treatments was systematic to account for the variable of time of collection, and each trial included a small, medium, and large urchin to maintain a balanced size distribution throughout (Supplementary Summary Tables). Seawater parameters in the trials were measured using a Thermo Scientific Orion Star A320 optical DO probe (accuracy $\pm 0.1 \mathrm{mg} / \mathrm{L}$ ), a Mettler Toledo SevenGo Handheld $\mathrm{pH}$ probe calibrated daily with NBS buffers 4, 7, 10 (accuracy \pm 0.002 ), and an Omega high precision thermocouple ( $\pm 0.05 \%$ reading accuracy). Salinity was recorded daily with a handheld multi-parameter YSI Pro2013 $( \pm 0.5 \%$ reading accuracy).

Temperature, $\mathrm{pH}, \mathrm{DO}$, and salinity were measured in the field on collection days, throughout the holding period (preexperiment), throughout the acclimation period, and during each trial. The conditions experienced by each sea urchin were tracked. Despite necessary variation in the date of collection and time in holding tanks, we maintained similar conditions across all treatments and maintained a strict balance across the unavoidable time constraints of the experiments (Supplementary Summary Tables).

\section{Analysis}

The effects of $\mathrm{pH}, \mathrm{DO}$, temperature, and in the second experiment, $\mathrm{pH}$ acclimation, on righting success were analyzed with generalized linear models (GLM) using a binominal distribution and a logit link function. The test diameter of each individual was included as a covariate. The date of collection was included as a covariate in experiment 1 , while the days of pre-experiment holding time and acclimation period start date were included as covariates in experiment 2 . Fully factorial models were analyzed with step-wise removal of non-significant interactions based on the $p$-values $(p>0.1)$ (Crawley, 2012). The main effects and covariates were retained in the reduced models. Residual plots were used to assess the quality of model fit (Zuur et al., 2010). In the second experiment, separation was indicated due to the high number of individuals that succeeded, and a Firth penalized likelihood method was employed using the logistf package in R. Analyses with and without the Firth option identified the same significant factors so we retained the model without this correction. Results from experimental assays were analyzed with $\mathrm{R}$ v. 3.6.2 (R Core Team, 2020).

\section{RESULTS}

\section{Environmental Conditions}

Weekly monitoring data show the shallow waters in and around Almirante Bay occasionally experience conditions that are hot, hypoxic, and acidic. Within the last 3 years during the day, temperatures above the seafloor (depth $\sim 15-20 \mathrm{~m}$ ) ranged from 26.52 to $30.76^{\circ} \mathrm{C}$ (mean $\left.=28.8^{\circ} \mathrm{C} \pm 0.9 \mathrm{SD}\right)$, DO ranged from 0.06 to $6.42 \mathrm{mg} / \mathrm{L}($ mean $=3.84 \pm 1.9 \mathrm{mg} / \mathrm{L})$ and $\mathrm{pH}$ ranged from 7.58 to 8.55 (mean $=8.04 \pm 0.2 \mathrm{SD}$ ) (Table 2 and Figure 3). There was a clear negative relationship between oxygen and temperature, and a positive correlation between DO and $\mathrm{pH}$ (Figure 3). The relationship between these parameters was similar among all seven sites, but the sites further from the mainland were less frequently hot, hypoxic, and acidic compared to the sites closer to the mainland (i.e., Colon vs. Almirante; Figure 3). The extreme values on the lower limits of the $\mathrm{pH}$ and DO ranges occurred between July and December 2019.

The hourly 3-month time-series on the Hospital Point reef, where animals were collected for experiments, experienced large diel fluctuations in $\mathrm{pH}$ and $\mathrm{DO}$ that scaled with increased temperature. Temperatures ranged from 27.6 to $32.7^{\circ} \mathrm{C}$ (mean $=29.8^{\circ} \mathrm{C} \pm 0.8 \mathrm{SD}$ ), $\mathrm{pH}$ ranged from 7.81 to 8.64 (mean $=8.09 \pm 0.14 \mathrm{SD}$ ), and DO ranged from 0.81 to $13.89 \mathrm{mg} / \mathrm{L}$, with a mean value of $5.21 \mathrm{mg} / \mathrm{L} \pm 1.72 \mathrm{SD}$ (Table 2 and Figure 4). Low DO values coincided with low $\mathrm{pH}$ values during the night, while warmer temperatures generally occurred during the day when $\mathrm{pH}$ and $\mathrm{DO}$ were both higher. There were only a few instances when DO values remained under $1.5 \mathrm{mg} / \mathrm{L}$ and temperatures above $32^{\circ} \mathrm{C}$ (e.g., 25 September 2019). These extreme conditions persisted for no more than $4 \mathrm{~h}$ at a time (Figure 4).

\section{Experiments}

For experiment 1, after step-wise removal of non-significant interactions, there was a significant main effect of oxygen on the righting success of E. lucunter ( $p<0.001$; Table 3 and Figure 5). No effect of temperature or $\mathrm{pH}$ was found. Under normoxic conditions $98.8 \% \pm 1.1 \mathrm{SE}$ of the animals righted successfully in $10 \mathrm{~min}$, while only $67.9 \% \pm 5.1 \mathrm{SE}$ righted successfully in the hypoxic treatments. Animal size did not differ significantly between our treatments, but was a significant covariate, with larger animals less likely to right than small ones regardless of the treatment $(p=0.020)$. This is a normal and expected response found in multiple sea urchin species in laboratory studies (Challener and McClintock, 2017).

For experiment 2, after step-wise removal of non-significant interactions, there were significant main effects of oxygen $(p=0.005)$, temperature $(p=0.029)$ and $\mathrm{pH}$ acclimation $(p=0.007)$, with no significant interaction effects on righting success (Table 3 and Figure 6). Righting success under normoxia was $99.3 \% \pm 0.67 \mathrm{SE}$, while under hypoxia, it was reduced by $9.6 \%(90 \% \pm 2.4 \mathrm{SE})$. Righting success was also reduced under warmer temperatures: $98 \% \pm 1.1 \mathrm{SE}$ at ambient and $91.3 \% \pm 2.3$ at the high temperature. Unexpectedly, acclimation to low $\mathrm{pH}$ for 7 days resulted in an $8.1 \%$ increase in righting success compared to "control" $\mathrm{pH}$ acclimated animals $(98.7 \% \pm 0.93$ $\mathrm{SE}$ compared to $90.6 \% \pm 2.3 \mathrm{SE}$, respectively) (Table 3 and Figure 6). Neither the experimental start date, number of days pre-experiment in holding tanks, or size had an effect on righting success.

In the first experiment, seven out of the total 172 urchins tested died within the $48 \mathrm{~h}$ recovery period after the trials. All except one of these individuals had been exposed to hypoxia. This one outlier was exposed to low $\mathrm{pH}$ and high temperature. In the second experiment, 15 out of a total of 299 died $48 \mathrm{~h}$ after trials. 


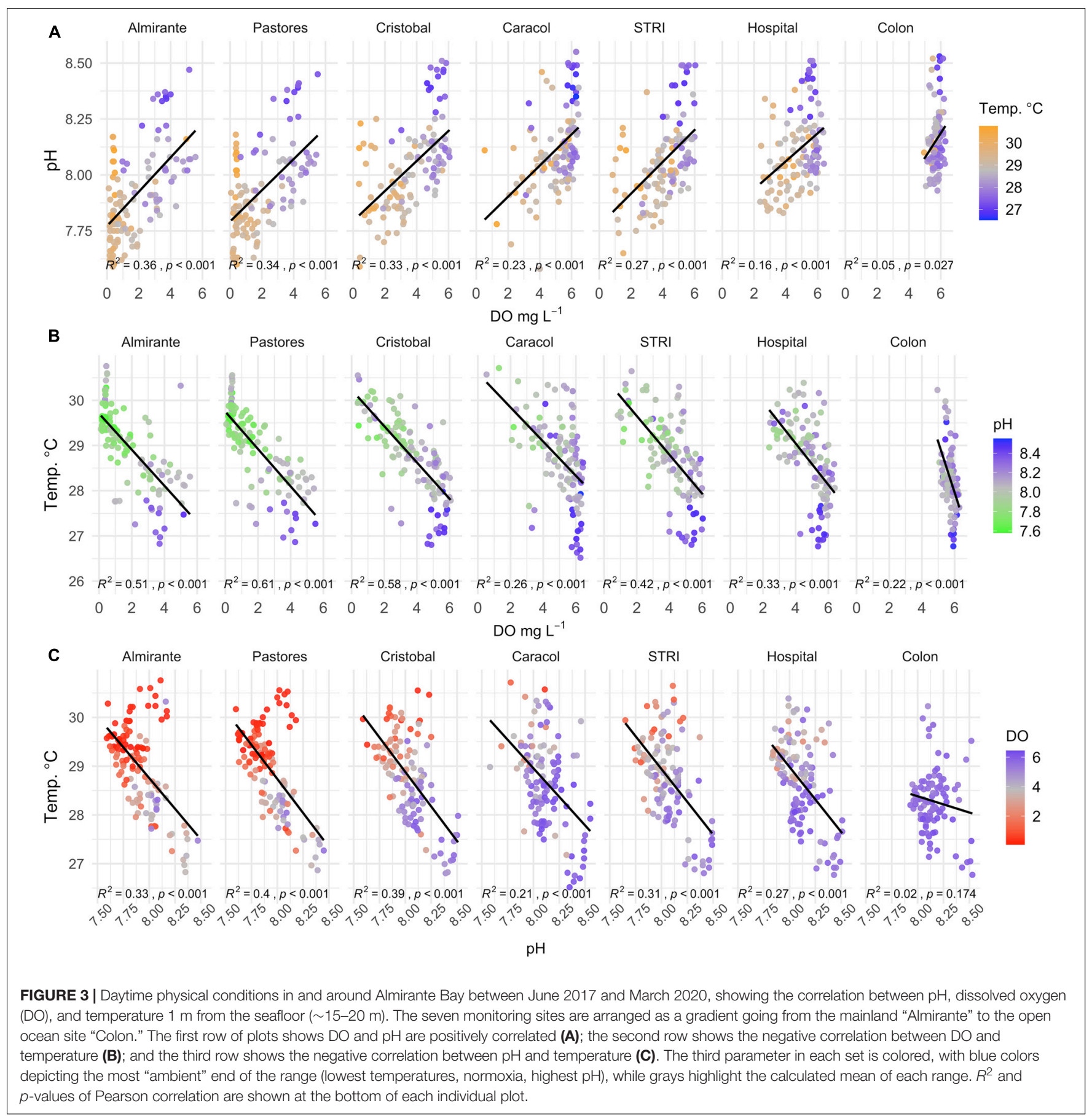

The prevalent stressor was temperature, with 13 of the 15 urchins exposed to high temperatures.

\section{DISCUSSION}

\section{Impacts of Multiple Stressors}

Experiments examining the impacts of factorial combinations of multiple stressors provide two important insights into potential real-world responses of organisms to these stressors.
They provide information on the relative importance of the stressors and crucially, for factors that co-vary in nature, if the impact of the combined stressors is greater than the individual stressors. However, results can vary based on the levels and durations of the stressors used. Here we aimed to determine which stressors are the most important for the performance of a tropical herbivore, near the center of its range, and under current day extremes. Short-term exposures were used as these stressors show pronounced diel cycles (see below). 


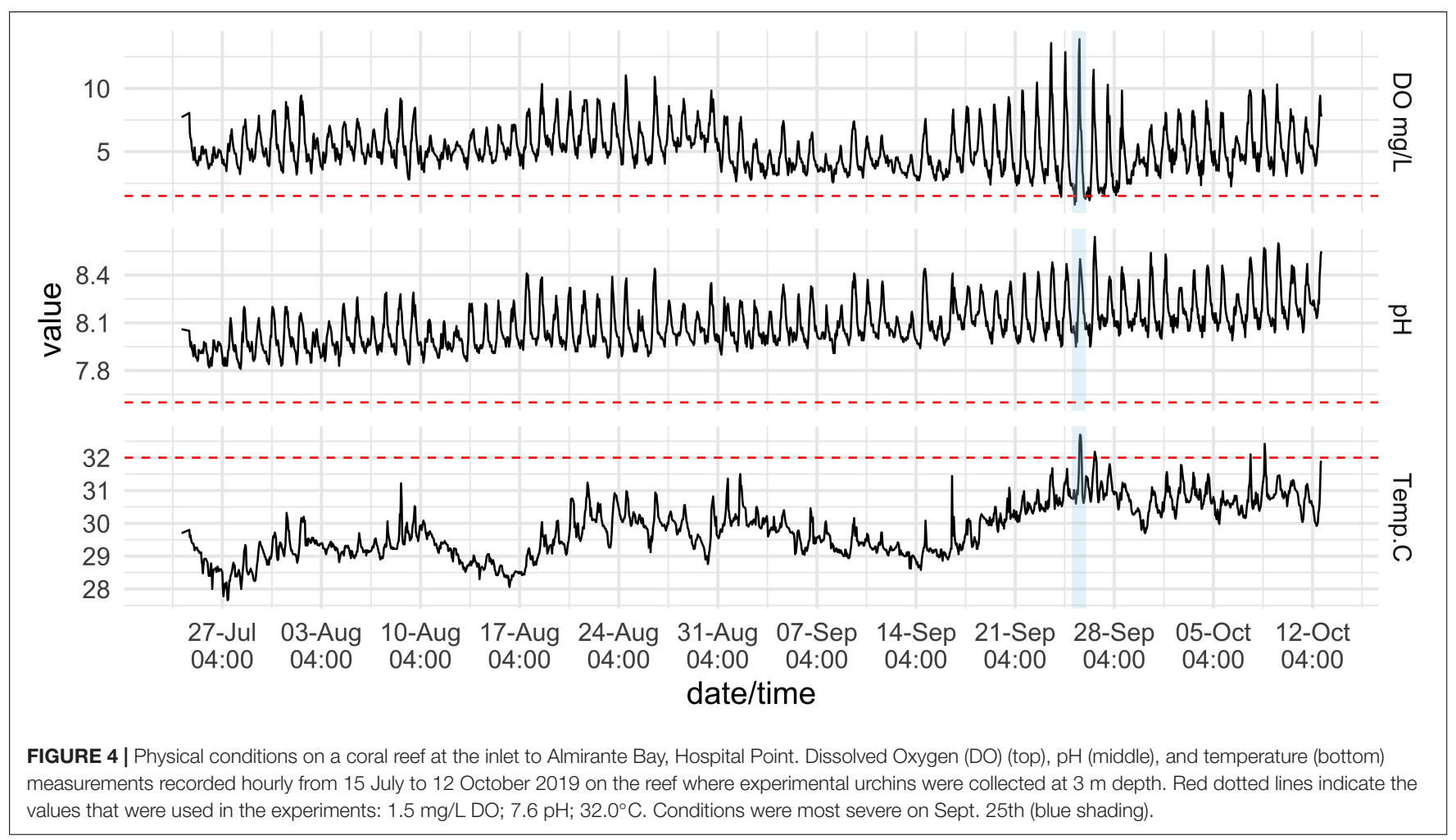

Of temperature, $\mathrm{pH}$, and $\mathrm{DO}$ concentration, we found that DO had the largest negative effect on sea urchin performance in both of our experiments. Warmer temperatures showed a negative effect in the second experiment but not in the first, and short-term exposures to low $\mathrm{pH}$ appeared

TABLE 3 | Effect of temperature, oxygen, and pH on righting success in both experiments, determined with GLMs.

\begin{tabular}{llcccc}
\hline & Factor & Estimate & Std. error & $\boldsymbol{Z}$-value & $\boldsymbol{P}$-value \\
\hline Exp. 1 & Intercept & 9.52 & 5.48 & 1.7 & 0.080 \\
& Oxygen & $\mathbf{3 . 9 0}$ & $\mathbf{1 . 0 5}$ & $\mathbf{3 . 7}$ & $<\mathbf{0 . 0 0 1}$ \\
& Temperature & -0.14 & 0.16 & -0.8 & 0.400 \\
pH & 0.07 & 0.49 & 0.1 & 0.880 \\
& Size (test diameter) & $-\mathbf{0 . 1 2}$ & $\mathbf{0 . 0 5}$ & $-\mathbf{2 . 4}$ & $\mathbf{0 . 0 2 0}$ \\
& Date of collection & -0.31 & 0.20 & -1.6 & 0.110 \\
Exp. 2 & Intercept & 2.23 & 2.42 & 0.9 & 0.355 \\
& Oxygen & $\mathbf{3 . 0 4}$ & $\mathbf{1 . 0 9}$ & $\mathbf{2 . 8}$ & $\mathbf{0 . 0 0 5}$ \\
& Temperature & $-\mathbf{1 . 6 3}$ & $\mathbf{0 . 7 5}$ & $-\mathbf{2 . 2}$ & $\mathbf{0 . 0 2 9}$ \\
& pH & 0.44 & 0.77 & 0.6 & 0.566 \\
& pH acclimation & $\mathbf{2 . 1 7}$ & $\mathbf{0 . 8 0}$ & $\mathbf{2 . 7}$ & $\mathbf{0 . 0 0 7}$ \\
& Size (test diameter) & -0.38 & 0.74 & -0.5 & 0.603 \\
& Holding time & 0.09 & 0.07 & 1.3 & 0.188 \\
Experiment Start & 0.01 & 0.08 & 0.2 & 0.881 \\
\hline
\end{tabular}

In Experiment 1, stepwise removal of non-significant interactions was made from the fully factorial model with collection data and animal size as covariates. Experiment 2 models included the additional effect of acclimation $\mathrm{pH}$, with experimental start date and holding time as covariates. Nesting trial replicate as a random effect in mixed models produced similar results, but are not reported due to over-parameterization issues. to have no impact. As low $\mathrm{pH}$ has been previously demonstrated to have particularly detrimental effects on calcifying sea urchins (Shirayama and Thornton, 2005; Courtney et al., 2013), we included an unrealistically long exposure to low $\mathrm{pH}$ in the second experiment, which had a substantial significant positive impact on performance. In neither experiment did we detect significant interactions between stressors, showing that despite the proposed mechanistic link between temperature and oxygen availability, the performance outcomes in this system are independent at these exposures. Taken together these results show that $\mathrm{DO}$ concentration and temperature are the most important conditions to consider when predicting environmental impacts on adult E. lucunter populations and distribution.

Although producing consistent results in terms of the factor with the greatest effect (DO), the results of the two experiments differed with respect to the effect of temperature. It is possible that experimental timing contributed to this difference. The sea urchins in experiment 1 were collected at the start of the warm hypoxic season in May and had therefore been naturally acclimated to cooler and better oxygenated conditions in the field. The animals in experiment 2 were collected toward the end of this season in November and had therefore been naturally acclimated to warmer conditions. Chronically warmer temperatures may induce either increased thermal tolerance through acclimation (Angilletta, 2009; Huey et al., 2012; Botero et al., 2015) or may induce increased sensitivity (Stillman, 2003; Boyd et al., 2016), as may have been the case here. As with any study of wild-collected animals, any number of potential confounding effects could have 


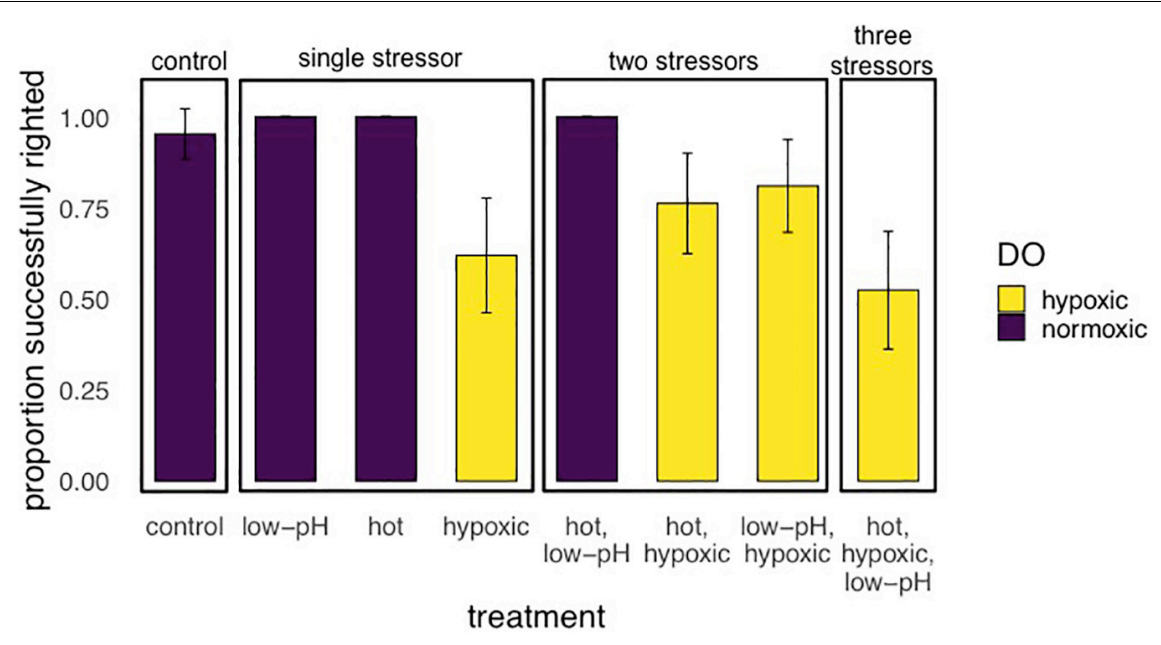

FIGURE 5 | Results of Experiment 1 showing the proportion (mean $\pm \mathrm{SE}$ ) of E. lucunter that were able to successful right after $2 \mathrm{~h}$ multi-stressor trials with levels of $\mathrm{pH}$ at 7.6 or 8.1 , DO 1.5 or $6.0 \mathrm{mg} / \mathrm{L}$, and temperatures of either 29 or $32^{\circ} \mathrm{C}$. Sea urchins had no experimental acclimation before the trials. Performance was negatively affected by treatments with hypoxia, which are indicated by the yellow bars $(p<0.001)$.

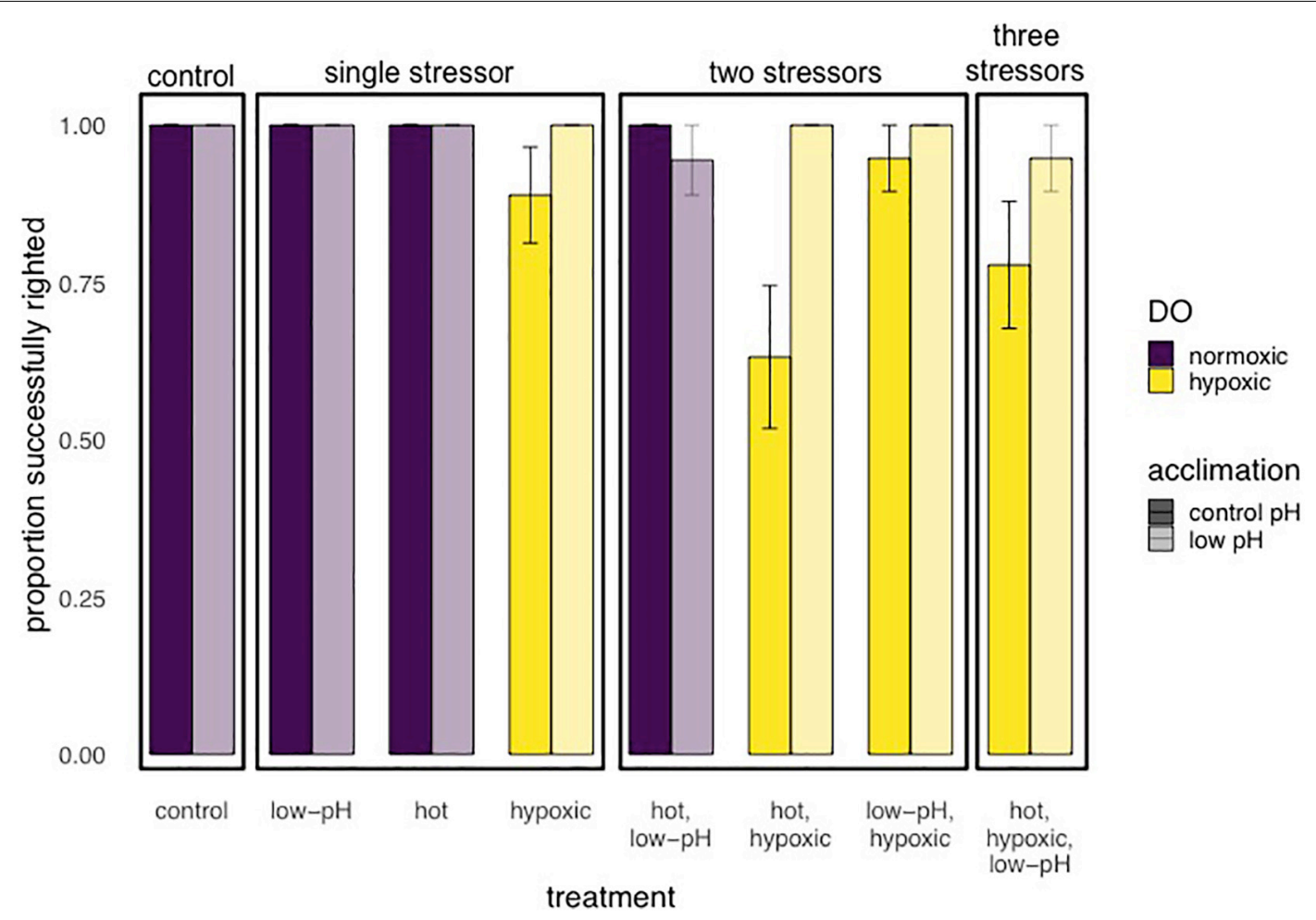

FIGURE 6 | Results of Experiment 2 showing the proportion (mean $\pm \mathrm{SE}$ ) of $E$. lucunter that were able to successful right after $2 \mathrm{~h}$ multi-stressor trials, with levels of $\mathrm{pH}$ at 7.6 or 8.1 , DO 1.5 or $6.0 \mathrm{mg} / \mathrm{L}$, and temperature either 29 or $32^{\circ} \mathrm{C}$. Prior to multi-stressor trials, animals were acclimated to either control (ambient) conditions (solid bars: $\mathrm{pH}$ 8.0) or low pH (lightly shaded bars $\mathrm{pH}$ 7.6). Performance was negatively affected by hypoxia, shown as yellow grouped bars ( $p=0.005)$, and higher temperatures $(p=0.029)$. Low $\mathrm{pH}$ acclimation significantly improved performance compared to control pH acclimation, shown as lightly shaded bars vs. solid bars, respectively $(p=0.007)$.

been experienced in the field. Unlike the physical conditions, we do not know if other factors like seawater nutrient conditions or diet quality vary seasonally and may have contributed to the inconsistent effect of temperature. Alternatively, the larger overall sample size in experiment 2 may have contributed to our ability to detect a moderately significant effect.

The most surprising experimental result of this study is that 7-day exposures to chronic low $\mathrm{pH}$ appeared to improve 
performance. Sea urchins acclimated to these conditions may have performed better than those that were kept in ambient control conditions because acclimation to low $\mathrm{pH}$ alters and improves the stress response. Some studies have shown that acclimation to one stressor may lead to increased tolerance for another, or a combination of different stressors (Todgham and Stillman, 2013). It has also been shown that a 2-year exposure to low $\mathrm{pH}$ and increased temperature positively influenced adult urchins through increased reproduction success (Suckling et al., 2015). Studies of other marine organisms have documented favorable impacts of reduced $\mathrm{pH}$ in combination with low oxygen as well. For example, Montgomery et al. (2019) found that lower $\mathrm{pH}$ increased hypoxia tolerance in a fish, due to increased affinity of red blood cells for oxygen under the lower $\mathrm{pH}$ conditions. Invertebrates that lack hemoglobin have also shown positive impacts of reduced $\mathrm{pH}$. The larvae of the barnacle Balanus amphitrite grow more slowly with low oxygen than under normoxia, but this reduction in growth is not evident when larvae are grown with low oxygen and low $\mathrm{pH}$ (Campanati et al., 2015). Several studies of adult sea urchins have indicated little impact of reduced $\mathrm{pH}$ on performance over the long term (e.g., Hazan et al., 2014; Moulin et al., 2014; Uthicke et al., 2016).

A hint at a possible mechanism behind the improved performance of sea urchins after acclimation to low $\mathrm{pH}$ was first given by Spicer (1995) who showed that in Psammechinus miliaris, as the partial pressure of oxygen $\left(p \mathrm{O}_{2}\right)$ decreased in the environment, it also decreased in the coelomic fluid. This was accompanied by an increase in $\mathrm{pH}$ in the coelomic fluid. Echinometra and Stongylocentrous species have also been shown to use bicarbonate compensation to regulate the acidbase balance of the coelomic fluid, to buffer over the long-term (Stumpp et al., 2012; Moulin et al., 2015), although this ability may vary among species or genera (Calosi et al., 2013). We note that while the acclimation potential and possible mitigating effects of low pH are conceptually interesting, it is not directly ecologically relevant for two reasons. First, the 7-day duration of the low $\mathrm{pH}$ acclimation used in our study was longer than any period of such extreme $\mathrm{pH}$ measured in the field. Second, while it is not unreasonable to assume that longer durations of $\mathrm{pH}$ and hypoxia are possible, or even likely, a low $\mathrm{pH}$ acclimation capacity may be irrelevant when such low $\mathrm{pH}$ conditions co-occur with extremely low and detrimental DO concentrations.

\section{Diel Variation and Environmental Extremes}

Our experiments focus on short-term exposures to multiple potential stressors as organisms are likely exposed to such conditions in the field. During the last 3 years of daytime monitoring, we found a significant correlation between temperature, $\mathrm{DO}$, and $\mathrm{pH}$, confirming that these variables covary. Within the last year, we found the lowest lows of $\mathrm{pH}$ and $\mathrm{DO}$, and highest highs of temperature. With continuous monitoring at an exposed, well-mixed shallow reef, we found distinct, even drastic, diel changes in $\mathrm{DO}$ and $\mathrm{pH}$. Our experimental results show that, not only could daytime values of DO and temperature be detrimental to E. lucunter, but that, as $\mathrm{DO}$ and $\mathrm{pH}$ are lowest at night, sites that may appear benign from daytime measures may experience stressful conditions during the night.
Although more environmental datasets are becoming available, numerous authors have cited the lack of welldocumented environmental conditions as an impediment to designing experiments that reflect realistic levels of stressors, their variability, and durations (Duarte et al., 2013; Gunderson et al., 2016; Hannan et al., 2020). Our continuous data show that average daily fluctuations of $4-5 \mathrm{mg} / \mathrm{L}$ in $\mathrm{DO}, 1-1.5^{\circ} \mathrm{C}$ in temperature and fluctuations of $0.3 \mathrm{pH}$ units are typical at this well-mixed site. These short-term fluctuations in conditions are not unique to this region. For example, a study of reefs in five locations around the world showed that average diel temperature changes ranged from $<0.5^{\circ} \mathrm{C}$ in Palmyra to $>3^{\circ} \mathrm{C}$ in Heron Island and that average diel $\mathrm{pH}$ changes ranged from $<0.05$ $\mathrm{pH}$ units in Bermuda to $\sim 0.3$ units in Heron Island (Cyronak et al., 2019). They also recorded similar variability at a another site in Almirante Bay, comparable to what we measured when conditions at the Hospital Point reef site where relatively cool. However, their 10-day dataset did not capture the variability in $\mathrm{DO}$ and $\mathrm{pH}$ that we found at the end of September, which occurred when temperature increased. In another study, all three stressors measured on shallow reefs in Hawaii over an 11-month period also showed similar ranges to our data (Guadayol et al., 2014). Previous work has shown that at a protected reef near the mainland (i.e., Almirante; Figure 2), daily fluctuations in DO can be as large as $8 \mathrm{mg} / \mathrm{L}$ (Lucey et al., 2020) and temperature can reach $33^{\circ} \mathrm{C}$ (Lucey unpublished). Due to the difficulties of continuous measurements over large spatial scales, none of these ranges may capture infrequent extreme values, but nevertheless show that even well mixed, semi-exposed sites can experience a suite of physiologically stressful conditions daily.

Diel variation is not specific to coral reef habitats, and shortterm variations in conditions have also been documented for a variety of other marine habitats. Diel cycles in conditions can be significant for planktonic animals whose vertical migrations may take them between different water masses. For example, in the Baltic Sea copepods experience changes of $5^{\circ} \mathrm{C}$ and 0.5 $\mathrm{pH}$ units during their diel migrations (Almén et al., 2014). Organisms living in mangrove pools in Panama can experience diel changes of as much as $0.5 \mathrm{pH}$ units, and $5^{\circ} \mathrm{C}$, ranging from 0 to $100 \%$ oxygen saturation (Gedan et al., 2017). Fluctuations in temperature and DO can be even greater in comparable habitats in Belize, while changes in pH were similar (Gedan et al., 2017). Large diel fluctuations are also documented in mangroves in Bermuda (Zablocki et al., 2011) and near mangroves, seagrass, and reefs in the Red Sea (Saderne et al., 2019). Mediterranean seagrass beds can experience diel DO ranges from 1.5 to $6.4 \mathrm{mg} / \mathrm{L}$, and diel $\mathrm{pH}$ ranges from 0.06 to 0.24 units (Saderne et al., 2019). Finally, temperate, subtropical, and tropical estuaries also experience extreme fluctuations in $\mathrm{DO}$, temperature, and $\mathrm{pH}$ (Baumann et al., 2014; Baumann and Smith, 2017). These studies suggest that large diel fluctuations in environmental conditions are more common than not in coastal ecosystems. Therefore, results from long-term static exposures to potential stressors may not reflect present or future environmental conditions or the organismal responses to them well. Since environmental conditions are often monitored during the day, experiments are likely underestimating the $\mathrm{DO}$ and $\mathrm{pH}$ stress that organism endure at night. Experiments that apply continuous conditions 
may also overestimate the detrimental effects of stressors from which animals may experience daily respite in the field (Shang et al., 2020).

In addition to highlighting the importance of diel fluctuations, we also show a significant correlation between temperature, $\mathrm{pH}$, and DO, which is evident over seven coastal sites during the last 3 years. These sites cover a spatial gradient from the mainland to the open ocean. A correlation between all three variables is evident at all sites along this gradient, albeit with relatively low $R^{2}$ values; however, these relationships are most significant in the sites closest to the mainland, such as "Almirante" on the far left, compared to sites closer to the open ocean, such as "Colon" on the far right, which has the lowest $R^{2}$ (Figure 3). This replicated relationship between $\mathrm{DO}, \mathrm{pH}$, and temperature in coastal waters emphasizes the importance of considering multiple stressors in experimental designs. We used the extreme values measured in the bay to parameterize our experiments, to represent local conditions. The temperatures and DO values measured on the reef were occasionally more extreme than our experimental values, but neither the site from which we collected the animals nor the well-exposed long-term monitoring site nearby experienced $\mathrm{pH}$ as low as our experimental treatment. Such low $\mathrm{pH}$ values were, however, measured at sites within $5 \mathrm{~km}$ away, and given the correlation between the variables seen in the long-term monitoring dataset, and the higher temperature and low DO measured on the reef, it may not be unreasonable to assume a pH of 7.60 may occur at Hospital Point in the near future.

Our experiments were conducted in a year that appeared to be "normal" with respect to environmental conditions. Heatwaves are increasing in frequency in the Caribbean, and very warm years have been recently reported in 2010-2011, 2015, and 2017 (Muñiz-Castillo et al., 2019). The timing of these high temperatures coincided with two extreme hypoxic events at depth in Almirante Bay in 2010 and 2017, supporting the idea that episodic hypoxia and heat waves may also be correlated. If E. lucunter experiences reduced performance on some days during normal years, as demonstrated by our experiments, it is likely that their performance would be more significantly reduced in these extremely warm years. It should be noted that for tropical animals where normal temperatures may be within only a degree or two of the critical thermal maximum, smaller changes in temperature may be significantly more impactful than changes of a similar magnitude in temperate systems (Tewksbury et al., 2008). As E. lucunter is thought to live for at least 10 years (Ebert et al., 2008), most animals would now be expected to experience significantly stressful seasons several times during their lifetimes. This will likely be exacerbated by globally accelerating climate changes (Melzner et al., 2013).

\section{CONCLUSION}

Many studies of environmental stressors either fail to report the natural conditions which their study organisms normally experience and/or use conditions predicted to reflect stressful future conditions. Here we found the lowest lows of oxygen and $\mathrm{pH}$ occurred at night on a well-mixed Caribbean reef, and that these scaled with the increasing temperatures. We also show that oxygen, temperature, and $\mathrm{pH}$ co-vary along a coastal gradient from protected to well-flushed reefs. Of these three parameters, hypoxia had the largest negative impact on the performance of a key reef herbivore under realistic 2-h exposures. Warming was also detrimental, but to a lesser extent. Our study indicates that current-day environmental stressors may be pushing the physiological limits of marine organisms in coastal environments, and that in this tropical system, temperature and $\mathrm{DO}$ but not $\mathrm{pH}$ are key to adult performance and survival.

\section{DATA AVAILABILITY STATEMENT}

The original contributions presented in the study are included in the article/Supplementary Material, further inquiries can be directed to the corresponding author/s.

\section{AUTHOR CONTRIBUTIONS}

NL designed the experiment and collected the field data. NL and $\mathrm{EH}$ collected the animals and conducted the experiments. $\mathrm{NL}$ and RC analyzed the data and prepared the manuscript. All authors contributed to the article and approved the submitted version.

\section{FUNDING}

This work would not have been possible without the logistic support of the staff of the Bocas del Toro Research Station, permission to conduct research granted by the government of Panama (MiAmbiente permit \# SE/APHBO-2-18) and financial support from the Smithsonian Tropical Research Institute (STRI). NL was supported by an STRI postdoctoral fellowship, and EH by an STRI short-term fellowship. This is contribution 66 from the Smithsonian's MarineGEO and Tennenbaum Marine Observatories Network.

\section{ACKNOWLEDGMENTS}

We thank C. Cesar for conducting the alkalinity titrations, M. Johnson for field loggers, J. Paulus for field assistance, and A. Herwig for help with the experiments.

\section{SUPPLEMENTARY MATERIAL}

The Supplementary Material for this article can be found online at: https://www.frontiersin.org/articles/10.3389/fmars.2020. 588764/full\#supplementary-material 


\section{REFERENCES}

Almén, A.-K., Vehmaa, A., Brutemark, A., and Engström-Ost, J. (2014). Coping with climate change? Copepods experience drastic variations in their physicochemical environment on a diurnal basis. J. Exp. Mar. Biol. Ecol. 460, 120-128. doi: 10.1016/j.jembe.2014.07.001

Altieri, A. H., Harrison, S. B., Seemann, J., Collin, R., Diaz, R. J., and Knowlton, N. (2017). Tropical dead zones and mass mortalities on coral reefs. Proc. Natl. Acad. Sci. U.S.A. 114, 3660-3665. doi: 10.1073/pnas.1621517114

Angilletta, M. (2009). Thermal Adaptation: a Theoretical and Empirical Synthesis. Oxford: Oxford University Press.

Barry, J. P., Lovera, C., Buck, K. R., Peltzer, E. T., Taylor, J. R., Walz, P., et al. (2014). Use of a free ocean $\mathrm{CO} 2$ enrichment (FOCE) system to evaluate the effects of ocean acidification on the foraging behavior of a deep-sea urchin. Environ. Sci. Technol. 48, 9890-9897. doi: 10.1021/es501603r

Baumann, H., and Smith, E. M. (2017). Quantifying metabolically driven $\mathrm{pH}$ and oxygen fluctuations in US nearshore habitats at diel to interannual time scales. Estuaries Coast. 41, 1102-1117. doi: 10.1007/s12237-017-0321-3

Baumann, H., Wallace, R. B., Tagliaferri, T., and Gobler, C. J. (2014). Large natural $\mathrm{pH}, \mathrm{CO} 2$ and $\mathrm{O} 2$ fluctuations in a temperate tidal salt marsh on diel, seasonal, and interannual time scales. Estuaries Coast. 38, 220-231. doi: 10.1007/s12237014-9800-y

Bopp, L., Resplandy, L., Orr, J. C., Doney, S. C., Dunne, J. P., Gehlen, M., et al. (2013). Multiple stressors of ocean ecosystems in the 21st century: projections with CMIP5 models. Biogeosciences 10, 6225-6245. doi: 10.5194/bg-10-62252013

Botero, C. A., Weissing, F. J., Wright, J., and Rubenstein, D. R. (2015). Evolutionary tipping points in the capacity to adapt to environmental change. Proc. Natl. Acad. Sci. U.S.A. 112, 184-189. doi: 10.1073/pnas.1408589111

Boyd, P. W., Cornwall, C. E., and Davison, A. (2016). Biological responses to environmental heterogeneity under future ocean conditions. Glob. Chang. Biol. 22, 2633-2650. doi: 10.1111/gcb.13287

Breitburg, D., Levin, L. A., Oschlies, A., Grégoire, M., Chavez, F. P., Conley, D. J., et al. (2018). Declining oxygen in the global ocean and coastal waters. Science 359:eaam7240. doi: 10.1126/science.aam7240

Breitburg, D., Salisbury, J., Bernhard, J. M., Cai, W. J., Dupont, S., Doney, S. C., et al. (2015). And on top of all that coping with Ocean Acidification in the midst of many stressors. Oceanography 28, 48-61. doi: 10.5670/oceanog.2015.31

Brothers, C. J., and McClintock, J. B. (2015). The effects of climate-induced elevated seawater temperature on the covering behavior, righting response, and Aristotle s lantern reflex of the sea urchin Lytechinus variegatus. J. Exp. Mar. Biol. Ecol. 467, 33-38. doi: 10.1016/j.jembe.2015.02.019

Calosi, P., Rastrick, S. P. S., Graziano, M., Thomas, S. C., Baggini, C., Carter, H. A., et al. (2013). Distribution of sea urchins living near shallow water $\mathrm{CO} 2$ vents is dependent upon species acid-base and ion-regulatory abilities. Mar. Pollut. Bull. 73, 470-484. doi: 10.1016/j.marpolbul.2012.11.040

Campanati, C., Yip, S., Lane, A., and Thiyagarajan, V. (2015). Combined effects of low $\mathrm{pH}$ and low oxygen on the early-life stages of the barnacle Balanus amphitrite. ICES J. Mar. Sci. 73, 791-802. doi: 10.1093/icesjms/fsv221

Challener, R. C., and McClintock, J. B. (2017). In situ measurements of righting behavior in the common sea urchin Lytechinus variegatus: the importance of body size, substrate type, and covering material. Aquat. Biol. 26, 33-40. doi: $10.3354 / \mathrm{ab} 00669$

Cheng, L., Abraham, J., Hausfather, Z., and Trenberth, K. E. (2019). How fast are the oceans warming? Science 363, 128-129. doi: 10.1126/science.aa v7619

Claireaux, G., and Chabot, D. (2016). Responses by fishes to environmental hypoxia: integration through Fry's concept of aerobic metabolic scope. J. Fish Biol. 88, 232-251. doi: 10.1111/jfb.12833

Collin, R., Rendina, F., Goodwin, V., and Mccabe, S. (2018). Do tropical specialist sea urchins have higher thermal tolerances and optimal temperatures than their more widely distributed relatives? Mar. Ecol. Prog. Ser. 589, 157-170.

Courtney, T., Westfield, I., and Ries, J. B. (2013). CO2-induced ocean acidification impairs calcification in the tropical urchin Echinometra viridis. J. Exp. Biol. Ecol. 440, 169-175. doi: 10.1016/j.jembe.2012.11.013

Crawley, M. J. (2012). The R Book. Weinheim: Wiley.

Cyronak, T., Takeshita, Y., Courtney, T. A., Decarlo, E. H., Eyre, B. D., Kline, D. I., et al. (2019). Diel temperature and $\mathrm{pH}$ variability scale with depth across diverse coral reef habitats. Limnol. Oceanogr. Lett. 5, 193-203. doi: 10.1002/lol2. 10129

Diaz, R. J. (2001). Overview of hypoxia around the world. J. Environ. Qual. 30, 275-281. doi: 10.2134/jeq2001.302275x

Díaz-Asencio, L., Helguera, Y., Fernández-Garcés, R., and Gómez-Batista, M. (2015). Two-year temporal response of benthic macrofauna and sediments to hypoxia in a tropical semi-enclosed bay (Cienfuegos, Cuba). Rev. Biol. Trop. 64, 177-188. doi: 10.15517/rbt.v64i1.18519

Doney, S. C., Fabry, V. J., Feely, R. A., and Kleypas, J. A. (2009). Ocean acidification: the other CO2 problem. Ann. Rev. Mar. Sci. 1, 169-192. doi: 10.1146/annurev. marine.010908.163834

Duarte, C. M., Hendriks, I. E., Moore, T. S., Olsen, Y. S., Steckbauer, A., Ramajo, L., et al. (2013). Is Ocean acidification an open-ocean syndrome? Understanding anthropogenic impacts on seawater pH. Estuaries Coast. 36, 221-236. doi: 10. 1007/s12237-013-9594-3

Ebert, T. A., Russell, M. P., Gamba, G., and Bodnar, A. (2008). Growth, survival, and longevity estimates for the rock-boring growth, survival, and longevity estimates for the rock-boring sea urchin Echinometra lucunter (Echinodermata, Echinoidea) in Bermuda. Bull. Mar. Sci. 82, 381-403.

Farmanfarmaian, A., and Giese, A. C. (1963). Thermal tolerance and acclimation in the western purple sea urchin, Strongylocentrotus purpuratus. Physiol. Zool. 36, 237-243. doi: 10.1086/physzool.36.3.30152309

Farrell, A. P., Hinch, S. G., Cooke, S. J., Patterson, D. A., Crossin, G. T., and Mathes, M. T. (2008). Pacific salmon in hot water: applying aerobic scope models and biotelemetry to predict the success of spawning migrations Pacific salmon. Comp. Biol. 81, 697-708. doi: 10.1086/592057

Fry, F. E. J. (1971). "The effect of environmental factors on the physiology of fish," in Environmental Relations and Behavior, eds W. S. Hoar and D. J. Randall (London: Academic Press), 1-98. doi: 10.1016/s1546-5098(08)60146-6

Gedan, K. B., Altieri, A. H., Feller, I., Burrell, R., and Breitburg, D. (2017). Community composition in mangrove ponds with pulsed hypoxic and acidified conditions. Ecosphere 8:e02053. doi: 10.1002/ecs2.2053

Gobler, C. J., and Baumann, H. (2016). Hypoxia and acidification in ocean ecosystems: coupled dynamics and effects on marine life. Biol. Lett. 12:20150976. doi: 10.1098/rsbl.2015.0976

Gruber, N. (2011). Warming up, turning sour, losing breath: ocean biogeochemistry under global change. Philos. Trans. R. Soc. A Math. Phys. Eng. Sci. 369, 1980-1996. doi: 10.1098/rsta.2011.0003

Guadayol, O., Silbiger, N. J., Donahue, M. J., and Thomas, F. I. M. (2014). Patterns in temporal variability of temperature, oxygen and $\mathrm{pH}$ along an environmental gradient in a coral reef. PLoS One 9:e85213. doi: 10.1371/journal.pone.00 85213

Gunderson, A. R., Armstrong, E. J., and Stillman, J. H. (2016). Multiple stressors in a changing world: the need for an improved perspective on physiological responses to the dynamic marine environment. Ann. Rev. Mar. Sci. 8, 357-378. doi: 10.1146/annurev-marine-122414-033953

Hannan, K. D., Miller, G. M., Rummer, J. L., Fabricius, K., and Munday, P. L. (2020). Diel pCO2 variation among coral reefs and microhabitats at Lizard Island, Great Barrier Reef. Coral Reefs 39, 1391-1406. doi: 10.1007/s00338-02001973-z

Hazan, Y., Wangensteen, O. S., and Fine, M. (2014). Tough as a rock-boring urchin: adult Echinometra sp. from the Red Sea show high resistance to ocean acidification over long-term exposures. Mar. Biol. 161, 2531-2545. doi: 10.1007/ s00227-014-2525-4

Huey, R. B., Kearney, M. R., Krockenberger, A., Holtum, J. A. M., Jess, M., and Williams, S. E. (2012). Predicting organismal vulnerability to climate warming: roles of behaviour, physiology and adaptation. Philos. Trans. R. Soc. B Biol. Sci. 367, 1665-1679. doi: 10.1098/rstb.2012.0005

Hughes, D. J., Alderdice, R., Cooney, C., Kühl, M., Pernice, M., Voolstra, C. R., et al. (2020). Coral reef survival under accelerating ocean deoxygenation. Nat. Clim. Chang. 10, 296-307. doi: 10.1038/s41558-020-0737-9

Humphreys, M. P. (2017). Climate sensitivity and the rate of ocean acidification: future impacts, and implications for experimental design. ICES J. Mar. Sci. 74, 934-940. doi: 10.1093/icesjms/fsw189

IPCC (2019). The Ocean and Cryosphere in a Changing Climate. Geneva: IPCC.

Johnson, M. D., Rodriguez, L. M., and Altieri, A. H. (2018). Shallow-water hypoxia and mass mortality on a Caribbean coral reef. Bull. Mar. Sci. 94, 143-144. doi: $10.5343 / \mathrm{https}$ 
Keeling, R. E., Körtzinger, A., and Gruber, N. (2010). Ocean deoxygenation in a warming world. Ann. Rev. Mar. Sci. 2, 199-229. doi: 10.1146/annurev.marine. 010908.163855

Keppel, A. G., Breitburg, D. L., and Burrell, R. B. (2016). Effects of co-varying dielcycling hypoxia and $\mathrm{pH}$ on growth in the juvenile eastern oyster, Crassostrea virginica. PLoS One 11:e0161088. doi: 10.1371/journal.pone.0161088

Kim, T. W., Barry, J. P., and Micheli, F. (2013). The effects of intermittent exposure to low-pH and low-oxygen conditions on survival and growth of juvenile red abalone. Biogeosciences 10, 7255-7262. doi: 10.5194/bg-10-7255-2013

Kleitman, N. (1941). The effect of temperature on the righting of echinoderms. Biol. Bull. 80, 292-298. doi: 10.2307/1537716

Knutson, T. R., McBride, J. L., Chan, J., Emanuel, K., Holland, G., Landsea, C., et al. (2010). Tropical cyclones and climate change. Nat. Geosci. 3, 157-163.

Kroeker, K. J., Kordas, R. L., Crim, R. N., and Singh, G. G. (2010). Meta-analysis reveals negative yet variable effects of ocean acidification on marine organisms. Ecol. Lett. 13, 1419-1434. doi: 10.1111/j.1461-0248.2010.01518.x

Laboy-Nieves, E. N., Klein, E., Conde, J. E., Losada, F., Cruz, J. J., and Bone, D. (2001). Mass mortality of tropical marine communities in Morrocoy, Venezuela. Bull. Mar. Sci. 68, 163-179.

Lawrence, J. M., and Cowell, B. C. (1996). The righting response as an indication of stress in Stichaster striatus (Echinodermata, Asteroidea). Mar. Freshw. Behav. Physiol. 27, 239-248. doi: 10.1080/10236249609378969

Le Quéré, C., Raupach, M. R., Canadell, J. G., and Marland, G. (2009). Trends in the sources and sinks of carbon dioxide. Nat. Geosci. 2, 831-836. doi: 10.1038/ ngeo689

Lonholdt, J. (ed.). (2005). (Water) and Wastewater Management in the Tropics. London: IWA Publishing.

Lucey, N. M., Collins, M., and Collin, R. (2020). Oxygen-mediated plasticity confers hypoxia tolerance in a corallivorous polychaete. Ecol. Evol. 10, 11451157. doi: 10.1002/ece3.5929

McLean, R. F. (1967). Erosion of burrows in Beachrock by the tropical sea urchin, Echinometra lucunter. Can. J. Zool. 45, 586-588. doi: 10.1139/ z67-072

McPherson, B. F. (1965). Studies on the biology of the tropical sea urchins, Echinometra lucunter and Echinometra viridis. Bull. Mar. Sci. 19, 194-213.

Melzner, F., Thomsen, J., Koeve, W., Oschlies, A., Gutowska, M. A., Bange, H. W., et al. (2013). Future ocean acidification will be amplified by hypoxia in coastal habitats. Mar. Biol. 160, 1875-1888. doi: 10.1007/s00227-012-1954-1

Montgomery, D. W., Simpson, S. D., Engelhard, G. H., Birchenough, S. N. R., and Wilson, R. W. (2019). Rising CO2 enhances hypoxia tolerance in a marine fish. Sci. Rep. 9:15152.

Moulin, L., Grosjean, P., Leblud, J., Batigny, A., Collard, M., and Dubois, P. (2015). Long-term mesocosms study of the effects of ocean acidification on growth and physiology of the sea urchin Echinometra mathaei. Mar. Environ. Res. 103, 103-114. doi: 10.1016/j.marenvres.2014.11.009

Moulin, L., Grosjean, P., Leblud, J., Batigny, A., and Dubois, P. (2014). Impact of elevated pCO2 on acid - base regulation of the sea urchin Echinometra mathaei and its relation to resistance to ocean acidification: a study in mesocosms. J. Exp. Mar. Biol. Ecol. 457, 97-104. doi: 10.1016/j.jembe.2014.04.007

Muñiz-Castillo, A. I., Rivera-Sosa, A., Chollett, I., Eakin, C. M., Andrade-Gómez, L., Mcfield, M., et al. (2019). Three decades of heat stress exposure in Caribbean coral reefs: a new regional delineation to enhance conservation. Sci. Rep. 9:11013.

Nelson, H. R., and Altieri, A. H. (2019). Oxygen: the universal currency on coral reefs. Coral Reefs 38, 177-198. doi: 10.1007/s00338-01901765-0

Ng, C. A., and Micheli, F. (2020). Short-term effects of hypoxia are more important than effects of ocean acidification on grazing interactions with juvenile giant kelp (Macrocystis pyrifera). Sci. Rep. 10:5403.

Perricone, V., and Collin, R. (2019). Larvae of Caribbean echinoids have small warming tolerances for chronic stress in Panama. Biol. Bull. 236, 115-129. doi: $10.1086 / 701666$

Pörtner, H. O. (2010). Oxygen- and capacity-limitation of thermal tolerance: a matrix for integrating climate-related stressor effects in marine ecosystems. J. Exp. Biol. 213, 881-893. doi: 10.1242/jeb.037523

Pörtner, H. O., and Farrell, A. P. (2008). Physiology and climate change. Science 322, 690-692. doi: 10.1126/science.1163156
Pörtner, H. O., and Peck, M. A. (2010). Climate change effects on fishes and fisheries: towards a cause-and-effect understanding. J. Fish Biol. 77, 1745-1779. doi: 10.1111/j.1095-8649.2010.02783.x

R Core Team (2020). R: A Language and Environment for Statistical Computing. Vienna: R Foundation for Statistical Computing.

Reum, J. C. P., Alin, S. R., Harvey, C. J., Bednarsek, N., Evans, W., Feely, R. A., et al. (2016). Interpretation and design of ocean acidification experiments in upwelling systems in the context of carbonate chemistry co-variation with temperature and oxygen. ICES J. Mar. Sci. 73, 582-595. doi: 10.1093/icesjms/ fsu231

Saderne, V., Baldry, K., Anton, A., Agusti, S., and Duarte, C. M. (2019). Characterization of the $\mathrm{CO} 2$ system in a coral reef, a seagrass meadow and a mangrove forest in the central Red Sea. J. Geophys. Res. 124, 7513-7528. doi: 10.1029/2019JC015266

Sangil, C., and Guzman, H. M. (2016). Assessing the herbivore role of the seaurchin Echinometra viridis: keys to determine the structure of communities in disturbed coral reefs. Mar. Environ. Res. 120, 202-213. doi: 10.1016/j. marenvres.2016.08.008

Schmidtko, S., Stramma, L., and Visbeck, M. (2017). Decline in global oceanic oxygen content during the past five decades. Nature 542, 335-351. doi: 10.1038/ nature 21399

Schoppe, S., and Werding, B. (1996). The boreholes of the sea urchin genus Echinoidea: Echinometridae as a microhabitat in tropical South America. Mar. Ecol. 17, 181-186. doi: 10.1111/j.1439-0485.1996.tb00499.x

Shang, Y., Wang, X., Deng, Y., Wang, S., Gu, H., Wang, T., et al. (2020). Dielcycling seawater acidification and hypoxia impair the physiological and growth performance of marine mussels. Sci. Total Environ. 722:138001. doi: 10.1016/j. scitotenv.2020.138001

Shirayama, Y., and Thornton, H. (2005). Effect of increased atmospheric CO2 on shallow water marine benthos. J. Geophys. Res. 110:C09S08. doi: 10.1029/ 2004JC002618

Spicer, J. I. (1995). Oxygen and acid-base status of the sea urchin Psammechinus miliaris during environmental hypoxia. Mar. Biol. 124, 71-76. doi: 10.1007/ bf00349148

Steneck, R. S. (2020). Regular Sea Urchins as Drivers of Shallow Benthic Marine Community Structure, 4th Edn. Amsterdam: Elsevier B.V. doi: 10.1016/B9780-12-819570-3.00015-9

Stillman, J. H. (2003). Acclimation capacity underlies susceptibility to climate change. Science 301:65. doi: 10.1126/science.1083073

Stumpp, M., Trübenbach, K., Brennecke, D., Hu, M. Y., and Melzner, F. (2012). Resource allocation and extracellular acid - base status in the sea urchin Strongylocentrotus droebachiensis in response to CO2 induced seawater acidification. Aquat. Toxicol. 111, 194-207. doi: 10.1016/j.aquatox.2011. 12.020

Suckling, C. C., Clark, M. S., Richard, J., Morley, S. A., Thorne, M. A. S., Harper, E. M., et al. (2015). Adult acclimation to combined temperature and $\mathrm{pH}$ stressors significantly enhances reproductive outcomes compared to short-term exposures. J. Anim. Ecol. 84, 773-784. doi: 10.1111/1365-2656.12316

Tewksbury, J. J., Huey, R. B., and Deutsch, C. A. (2008). Ecology. Putting the heat on tropical animals. Science 320, 1296-1297. doi: 10.1126/science.11 59328

Todgham, A. E., and Stillman, J. H. (2013). Physiological responses to shifts in multiple environmental stressors: relevance in a changing world. Integr. Comp. Biol. 53, 539-544. doi: 10.1093/icb/ict086

Tyler, R. M., Brady, D. C., and Targett, T. E. (2009). Temporal and spatial dynamics of diel-cycling hypoxia in estuarine tributaries. Estuaries Coast. 32, 123-145. doi: 10.1007/s12237-008-9108-x

Uthicke, S., Ebert, T., Liddy, M., and Johansson, C. (2016). Echinometra sea urchins acclimatized to elevated pCO2 at volcanic vents outperform those under present-day pCO2 conditions. Glob. Chang. Biol. 22, 2451-2461. doi: $10.1111 /$ gcb. 13223

van Tussenbroek, B. I., Hernández, H. A., Rodríguez-Martínez, R. E., EspinozaAvalos, J., Canizales-Flores, H. M., González-Godoy, C. E., et al. (2017). Severe impacts of brown tides caused by Sargassum spp. on near-shore Caribbean seagrass communities. Mar. Pollut. Bull. 122, 272-281. doi: 10.1016/ j.marpolbul.2017.06.057

Verberk, W. C. E. P., Overgaard, J., Ern, R., Bayley, M., Wang, T., Boardman, L., et al. (2016). Does oxygen limit thermal tolerance in arthropods? A critical 
review of current evidence. Comp. Biochem. Physiol. A Mol. Integr. Physiol. 192, 64-78. doi: 10.1016/j.cbpa.2015.10.020

Yao, C. L., and Somero, G. N. (2014). The impact of ocean warming on marine organisms. Chin. Sci. Bull. 59, 468-479. doi: 10.1007/s11434-014-0113-0

Zablocki, J. A., Andersson, A. J., and Bates, N. R. (2011). Diel aquatic CO2 system dynamics of a Bermudian mangrove environment. Aquat. Biol. 17, 841-859. doi: 10.1007/s10498-011-9142-3

Zuur, A. F., Ieno, E. N., and Elphick, C. S. (2010). A protocol for data exploration to avoid common statistical problems. Stat. Methods Evol. Ecol. 1, 3-14. doi: 10.1111/j.2041-210X.2009.00001.x
Conflict of Interest: The authors declare that the research was conducted in the absence of any commercial or financial relationships that could be construed as a potential conflict of interest.

Copyright $\odot 2020$ Lucey, Haskett and Collin. This is an open-access article distributed under the terms of the Creative Commons Attribution License (CC BY). The use, distribution or reproduction in other forums is permitted, provided the original author(s) and the copyright owner(s) are credited and that the original publication in this journal is cited, in accordance with accepted academic practice. No use, distribution or reproduction is permitted which does not comply with these terms. 